\title{
Pemurnian Minyak Goreng Bekas Pakai (Jelantah) dengan Menggunakan Arang Bonggol Jagung
}

\author{
Fitri Choiri Hidayati ${ }^{1)}$, Masturi ${ }^{2)}$, Ian Yulianti ${ }^{3)}$ \\ ${ }^{1,2,3)}$ Pascasarjana Pendidikan Fisika. Universitas Negeri Semarang \\ ${ }^{1)}$ E-mail: si.fitrich@gmail.com
}

\begin{abstract}
Abstrak. Minyak goreng merupakan kebutuhan pokok bagi kehidupan manusia. Proses pemanasan tinggi pada minyak akan menghasilkan asam lemak bebas. Selain itu juga akan menghasilkan senyawa karbonil, dan peroksida yang dapat menyebabkan keracunan kronis pada manusia. Minyak goreng bekas yang terus menerus digunakan umumnya mengandung senyawa berbahaya tersebut. Penggunaan karbon dari tongkol jagung yang direkatkan dengan tepung kanji menjadi salah satu cara untuk memurnikan minyak bekas pakai tersebut. Berdasarkan hal tersebut, peneliti mencoba untuk melakukan penelitian bagaimana mengubah minyak bekas pakai (jelantah) menjadi minyak yang dapat dikonsumsi. Penelitian ini bertujuan untuk mengetahui apakah penggunaan karbon tongkol jagung dapat memurnikan minyak goreng bekas pakai (jelantah) serta dapat menurunkan kadar asam lemak bebasnya. Hasil dari penelitian ini adalah penggunaan karbon dari tongkol jagung terbukti dapat memurnikan minyak goreng bekas pakai, warna yang semula coklat kehitaman mengalami degradasi warna yang jernih, kandungan asam lemak bebasnya juga dihitung persentasenya dan didapat penurunan kadar minyak goreng bekas yang semula 1,62 \% menjadi 0,69 \%. Ini menunjukkan bahwa hasil FFA minyak bekas hasil pemurnian mendekati FFA mutu minyak goreng yang ditetapkan SNI syarat mutu minyak goreng yaitu sebesar $0,3 \%$.
\end{abstract}

Kata Kunci: Karbon, asam lemak bebas, senyawa karbonil, peroksida.

\section{PENDAHULUAN}

Minyak goreng merupakan kebutuhan yang tidak bisa terlepas bagi kebanyakan orang. Selain berfungsi sebagai media penghantar panas, minyak goreng juga berfungsi sebagai penambah rasa gurih makanan serta memperbaiki cita rasa makanan dengan membentuk warna kuning kecoklatan pada saat penggorengan. Proses pemanasan tinggi pada minyak akan menghasilkan asam lemak bebas. Selain itu juga akan menghasilkan senyawa karbonil, dan peroksida yang dapat menyebabkan keracunan kronis pada manusia. Minyak goreng bekas yang terus menerus digunakan umumnya mengandung senyawa berbahaya tersebut. Secara umum komponen utama yang sangat menentukan mutu minyak adalah asam lemaknya, karena asam lemak menentukan sifat kimia maupun stabilitas minyak. Dalam proses menggoreng, minyak berfungsi sebagai penghantar panas sehingga proses pemanasan menjadi lebih efisien dibandingkan proses pemanggangan dan perebusan. Proses penggorengan akan meningkatkan cita rasa, kandungan gizi dan daya awet serta menambah nilai kalori bahan pangan. Pada proses penggorengan oksigen dapat mengoksidasi minyak dengan cepat.

Kerusakan lemak selama proses penggorengan diakibatkan oleh kontak minyak dengan udara, pemanasan yang berlebihan, kontak minyak dengan bahan pangan dan adanya partikel-partikel yang gosong. Kerusakan minyak akibat pemanasan dapat dilihat dari perubahan warna, kenaikan kekentalan, kenaikan kandungan asam lemak bebas, kenaikan peroksida dan penurunan bilangan iodium. Kerusakan ini akan mempengaruhi mutu dan nilai gizi serta penampilan bahan pangan yang digoreng. Pemanfaatan minyak goreng bekas yang sudah dimurnikan tentu akan sangat membantu industri yang menggunakan minyak goreng dalam proses produksinya.

Penelitian sebelumnya yang dilakukan memperlihatkan bahwa pembuatan arang aktif untuk adsorben pemurnian minyak goreng bekas karena kandungan karbonnya yang tinggi. Hasil penelitian tersebut mengindikasikan bahwa limbah 


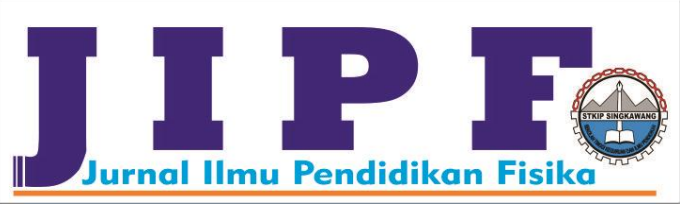

pertanian seperti bonggol jagung diduga dapat diolah lebih lanjut sebagai adsorben (arang aktif) terhadap minyak goreng bekas dan diharapkan mampu meningkatkan nilai tambah.

Di Indonesia, pertanian merupakan sektor yang sangat penting. Namun kegiatan setelah panen dan pengolahan hasil pertanian, termasuk pemanfaatan produk samping dan sisa pengolahannya masih kurang. Sisa pengolahan industri pertanian pada jagung akan menghasilkan limbah berupa bonggol jagung yang jumlahnya akan terus bertambah seiring dengan peningkatan kegiatan setelah panen. Produksi jagung di Indonesia setiap tahunnya menunjukkan peningkatan. Menurut Biro Pusat Statistik (BPS) Indonesia, angka produksi jagung tahun 2004 mencapai 11,2 juta ton [1]. Tahun 2005 meningkat menjadi 12,5 juta ton, tahun 2006 mencapai 12,13juta ton [1]. Tahun 2007 produksinya mencapai 14 juta ton [1]. Disamping itu, tingkat konsumsi jagung pada tahun 2006 sekitar 3,5 juta ton, sedangkan tahun 2007 diperkirakan mencapai 4,1 juta ton [1]. Banyaknya buah jagung yang dikonsumsi menyebabkan bertambahnya limbah bonggol jagung yang dapat menyebabkan pencemaran lingkungan.

Selama ini, masyarakat pedalaman cenderung memanfaatkan limbah bonggol jagung sebagai bahan bakar, dan terkesan terbuang percuma. Oleh karena itu, perlu dilakukan penelitian guna mengurangi volume limbah bonggol jagung dan meningkatkan nilai tambahnya. Salah satu upaya yang dilakukan untuk memanfaatkan limbah pertanian tersebut ialah diolah menjadi arang aktif yang selanjutnya diaplikasikan sebagai adsorben. Kandungan senyawa berkarbon, yaitu selulosa (41\%) dan hemiselulosa (36\%) yang cukup tinggi mengindikasikan bahwa bonggol jagung berpotensi sebagai bahan pembuat arang aktif.

Komposisi kandungan tongkol jagung dapat dilihat pada Tabel 1.
Jurnal Ilmu Pendidikan Fisika

Volum 1 Nomor 2 September 2016. Halaman 67-70 p-ISSN: 2477-5959 e-ISSN: 2477-8451

TABEL 1

KOMPOSISI BONGGOL JAGUNG (SUMBER: LORENZ \& KULP (1991))

\begin{tabular}{cc}
\hline Komponen & $\%$ \\
\hline Air & 9.6 \\
Abu & 1.5 \\
Hemiselulosa & 36.0 \\
Selulosa & 41.0 \\
Lignin & 6.0 \\
Pektin & 3.0 \\
Pati & 0.014 \\
\hline
\end{tabular}

Arang aktif merupakan arang yang telah diaktifkan oleh suatu zat sehingga memiliki daya adsorpsi dengan daya serap mencapai 3-7 kali dari daya serap arangnya. Arang aktif mampu menyerap anion, kation, dan molekul dalam bentuk senyawa organik dan anorganik berupa larutan dan gas sehingga digunakan sebagai adsorben polutan berkadar rendah pada produk-produk industri [2].

Menurut Jaguaribe (2005) kapasitas adsorpsi yang baik jika arang aktif berbentuk serbuk atau granul. Dewasa ini arang aktif banyak dimanfaatkan oleh pihak industri dalam proses pemurnian, seperti pemurnian gula, minyak dan lemak, kimia, farmasi, dan penjernihan air untuk mengadsorpsi bau, warna, gas, dan logam yang tidak diinginkan. Penelitian ini bertujuan memanfaatkan arang limbah bonggol jagung sebagai adsorben pemurnian minyak goreng bekas. Dalam pembuatan arang aktif, peneliti menggunakan tepung kanji sebagai perekat/pengikat butiran halus arang agar tidak larut dalam minyak jelantah.

\section{METODE}

\section{A. Penyiapan Bahan}

Bahan yang akan digunakan untuk mengabsorbsi minyak bekas diantaranya, arang dari bonggol jagung dan tepung kanji.

\section{B. Proses Penghalusan Arang Bonggol jagung}

Arang bonggol jagung ditumbuk secara halus menggunakan penumbuk sampai dihasilkan arang yang benar-benar halus. Kemudian arang disaring menggunakan penyaring. Hasil arang yang digunakan mempunyai ukuran relatif kecil. 


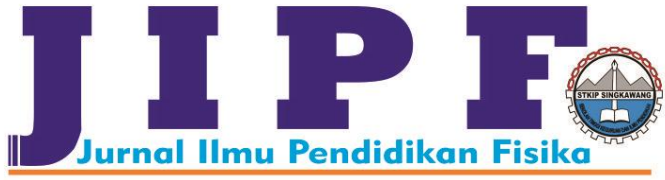

C. Proses pencampuran bahan

Pencampuran menggunakan metode sederhana. Tepung kanji yang telah ditimbang dicampurkan dengan hasil saringan arang bonggol jagung, sehingga membentuk adonan campuran yang bertekstur lembut. Hasil campuran kanji dan arang dibentuk menjadi butiranbutiran kecil kemudian butiran-butiran arang tersebut dioven hingga kering dan terasa ringan.

\section{Proses Pemurnian Minyak Goreng Bekas}

Arang aktif tersebut kemudian dimasukkan ke dalam minyak goreng bekas $180 \mathrm{ml}$ dengan memvariasi massa butiran arang yang digunakan sebanyak $5 \mathrm{~g}, 10 \mathrm{~g}, 15 \mathrm{~g}$. Variasi waktu perendaman butiran arang selama 12 jam untuk setiap perlakuan variasi massa.

\section{E. Penetapan kadar asam lemak bebas/ free fatty acid (FFA) (AOAC 1999)}

Sampel minyak ditimbang ke dalam Erlenmeyer $250 \mathrm{ml}$ dengan bobot $180 \mathrm{ml}$. Ke dalam sampel ditambahkan etanol 95\% panas dan indikator fenolftalein kemudian dikocok. Larutan dititrasi dengan larutan $\mathrm{NaOH} 0,1 \mathrm{~N}$ yang telah distandardisasi.

$$
\begin{array}{r}
\text { Kadar Asam Lemak Bebas (\%) } \\
\frac{m l N a O H x N \times B M}{g}
\end{array}
$$

dimana,

$$
\begin{array}{ll}
\mathrm{N} & =\text { Normalitas larutan } \mathrm{NaOH} \\
\mathrm{BM} & =\text { Bobot molekul asam laurat } \\
\mathrm{g} & =\text { Bobot sampel yang diuji }
\end{array}
$$

\section{RESULT AND DISCUSSION}

\section{A. Pemurnian minyak goreng bekas}

Komponen utama minyak yang sangat menentukan mutu minyak goreng adalah asam lemaknya, karena asam lemak menentukan sifat kimia maupun stabilitas minyak (Djatmiko 1974). Proses pemanasan pada minyak dapat menyebabkan minyak menjadi rusak. Salah satu parameter yang digunakan untuk melihat kerusakan minyak akibat pemanasan adalah kandungan asam lemak bebasnya.

Asam lemak bebas terbentuk karena proses oksidasi dan hidrolisis. Proses pemanasan pada suhu tinggi dan kontak minyak udara dapat mempercepat oksidasi. Sementara itu, proses hidrolisis dapat dipercepat karena adanya air.
Jurnal Ilmu Pendidikan Fisika

Volum 1 Nomor 2 September 2016. Halaman 67-70 p-ISSN: 2477-5959 e-ISSN: 2477-8451

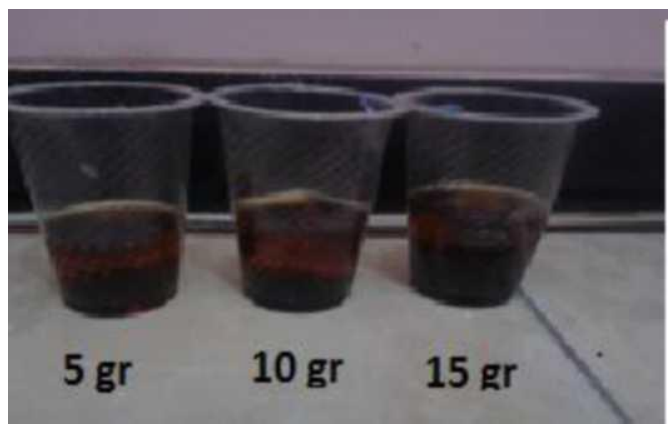

Gambar 1. Proses absorpsi minyak jelantah dengan arang tongkol jagung

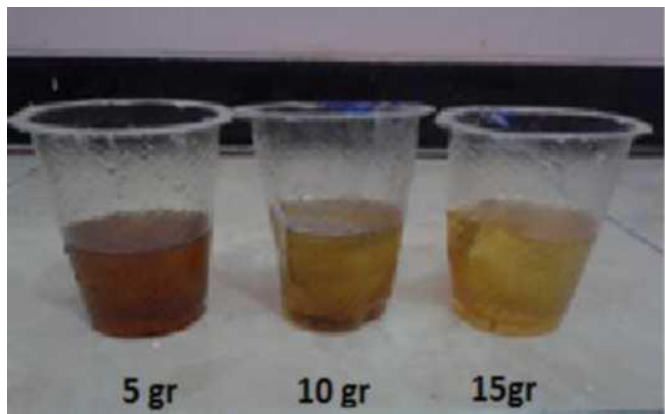

Gambar 2. Hasil pemurnian minyak goreng bekas

Berdasarkan absorpsi/ pemurnian minyak goreng bekas di atas, maka sampel yang diambil untuk dilakukan pengujian asam lemak bebasnya adalah sampel ke-3 dengan massa arang aktif 15 gr (12 jam), minyak goreng $180 \mathrm{ml}$, asam laurat $25 \mathrm{ml}, 50$ $\mathrm{ml} \mathrm{NaOH}$ dengan konsentrasi normalitas larutan $0,1 \mathrm{~N}$.

B. Analisis perhitungan kadar asam lemak bebas

$$
\frac{50 \mathrm{ml} \times 25 \mathrm{ml} \times 0,1 \mathrm{~N}}{180 \mathrm{ml}}=0,694 \%
$$

Data percobaan pemurnian minyak goreng bekas tersaji dalam Tabel berikut :

\section{TABEL 2}

HASIL ANALISIS MINYAK GORENG BEKAS

$$
\text { FFA }(\% \mathbf{b} / \mathbf{b})
$$

\begin{tabular}{cc}
\hline Sampel Minyak Goreng & Arang Aktif (5 gr, 12 jam) \\
\hline $\begin{array}{c}\text { Minyak goreng bekas sebelum } \\
\text { dimurnikan }\end{array}$ & 1,62 \\
$\begin{array}{c}\text { Minyak goreng bekas setelah } \\
\text { dimurnikan }\end{array}$ & 0,69 \\
\hline
\end{tabular}

Berdasarkan tabel diatas dapat dilihat bahwa ada penurunan kadar asam lemak bebas minyak goreng bekas setelah dimurnikan yaitu yang semula kadar FFA nya $1,62 \%$ menjadi $0,69 \%$. Hal ini menunjukkan bahwa penggunaan arang tongkol jagung dapat digunakan sebagai absorbance 


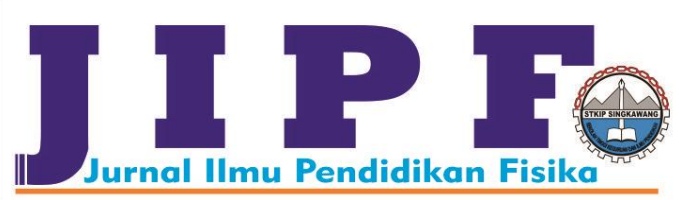

minyak goreng bekas pakai, selain warna degradasi minyak akibat pemurnian yang semakin jernih dan juga kandungan asam lemak bebas yang menurun membuat minyak goreng bekas ini menjadi bermanfaat lagi bagi para ibu rumah tangga maupun pedagang gorengan dan para pengguna lainnya.

\section{KESIMPULAN}

Penggunaan arang aktif dari limbah bonggol jagung dirasa menjadi suatu terobosan baru untuk memurnikan minyak goreng bekas pakai, dengan cara sederhana pembuatan arang aktif dari limbah bonggol jagung dan perekat tepung kanji ini membuat arang aktif ekonomis yang murah meriah. Berdasarkan hasil penelitian di atas menunjukkan bahwa proses pemurnian minyak goreng bergantung pada jumlah arang yang dipakai serta waktu perendaman karbon tersebut. Apabila arang yang dipakai lebih banyak, maka minyak bekas tersebut warnanya mendekati jernih.

Selain warna yang jernih, kandungan asam lemak bebasnya juga dihitung persentasenya dan didapat penurunan kadar minyak goreng bekas 5 yang semula $1,62 \%$ menjadi $0,69 \%$. Ini menunjukkan bahwa hasil FFA minyak bekas hasil pemurnian mendekati FFA mutu minyak goreng yang ditetapkan SNI syarat mutu minyak goreng yaitu sebesar $0,3 \%$.
Jurnal Ilmu Pendidikan Fisika

Volum 1 Nomor 2 September 2016. Halaman 67-70 p-ISSN: 2477-5959 e-ISSN: 2477-8451

\section{DAFTAR PUSTAKA}

[1] Badan Pusat Statistik, Indonesia. 2007. Luas Panen, Produktivitas, dan Produksi Tanaman Padi dan Palawija. Jakarta: BPS.

[2] Pari G. 1996. Pembuatan arang aktif dari serbuk gergajian sengon dengan cara kimia. Buletin Penelitian Hasil Hutan 14:308-320.

[3] Ferry J. 2002. Pembuatan arang aktif dari serbuk gergajian kayu campuran sebagai adsorben pada pemurnian minyak goreng bekas [skripsi]. Bogor: Fakultas Matematika dan Ilmu Pengetahuan Alam, Intitut Pertanian Bogor.

[4] Hudaya N, Hartoyo. 1990. Pembuatan Arang Aktif dari Tempurung Biji-Bijian Asal Tanaman Hutan dan Perkebunan. Jurnal Penelitian Hasil Hutan 8(4):146-149.

[5] Ketaren S. 1986. Pengantar Teknologi Minyak dan Lemak Pangan. Jakarta: UI Press.

[6] Pari G. 2004. Kajian struktur arang aktif dari serbuk gergajian kayu sebagai adsorben emisi formaldehida kayu lapis [disertasi]. Bogor: Program Pascasarjana, Institut Pertanian Bogor.

[7] PDII LIPI. 1998. Arang Aktif dari Tempurung Kelapa. Jakarta: PDII LIPI.

[8] Rasjiddin I. 2006. Pembuatan arang Aktif dari Tempurung Biji Jambu Mede (Anacardium cocidentale) Sebagai Adsorben Pada Pemurnian Minyak Goreng Bekas [skripsi]. Bogor: Fakultas Teknologi Pertanian, Institut Pertanian Bogor.

[9] SNI 01-3741-1995: Syarat Mutu Minyak Goreng. Jakarta: Dewan Standardisasi Nasional.

[10] Sriwahyuni W. 2002. Efektivitas adsorben dan koagulan-flokulan pada penjernihan air wilayah Marunda [skripsi]. Bogor: Fakultas Matematika dan Ilmu Pengetahuan Alam, Institut Pertanian Bogor.

[11] Sudradjat R, Soleh S. 1994. Petunjuk Teknis Pembuatan Arang Aktif Bogor: Puslitbang Hutan.

[12] Suryani, Ade Murni. 2009. Pemanfaatan tongkol jagung untuk pembuatan arang aktif sebagai adsorben pemurnian minyak goreng bekas. Bogor: Fakultas Matematika dan Ilmu Pengetahuan Alam, Intitut Pertanian Bogor. 